\title{
ENGLISH IN ELEMENTARY SCHOOLS.
}

II.

IN a former paper I spoke of the importance of imitation in the learning of language and of the student's great need in the elementary school, namely, more time for self-expression and for oral reading. The present paper takes up briefly the question of grammar.

Some thirty years ago it was discovered that the grammars of Brown and Greene were too hard for children, and the country has since been flooded with substitutes called language books. There was a sudden flowering of pedagogical interest in the child's attitude toward language. This flowering came at the same time with the invention of Sunday-school music and Sunday-school stories. The language books diluted the grammar in various ways. Bits of poetry alternated with discussions of nouns and verbs, and the child turned from the solemnity of Thanatopsis to that of object complements. Here and there appeared patches of useful information - bits of the biography of respectable poets, lists of common abbreviations, etc. Rules for punctuation and proof-reading sometimes appeared, as a neat compliment to the precocious child. The worst of these books taught neither grammar, literature, nor composition. The best of them taught a little of each. But, in spite of all faults, they marked a great advance in teaching English. There was an immense gain in sympathy and practicality. If any ambitious young writer doubts this, let him attempt to make a few textbooks that will do more for a child than an equal number of Mr. Swinton's did and can.

Latterly there are signs of a reaction in favor of formal grammar. A course of rather a stiff nature is now given in the last year of the grammar school, or even earlier. Probably the child of fourteen is now expected to analyze as well as his father did at sixteen. There are at least three reasons for the reaction. First, there is a desire to teach advanced studies to those whose 
schooling closes with the eighth school year. Secondly, there is a feeling that language books fail to produce the requisite degree of correctness in the student's speech. Thirdly, there is the desire to ground certain students in grammar before they begin Latin, French, or German.

For one, I believe that too much formal grammar is taught in the grammar school. I believe that most of the time now given to this subject might better be given to literature, or biography, or composition, or oral reading, or drill in oral English.

To.take up the causes of the reaction in order, what shall we say of the lad whose schooling is to cease with the grammar school? Does he need to be finished off with parsing and analysis? Parsing and analysis are good mental drill of a certain sort, but have they any magic not possessed by English composition? The average boy cannot, on leaving the grammar school, write a good business letter. He cannot narrate a day's happenings clearly. He cannot (in writing) describe his dog so that a stranger could identify it. I know that nowadays there is a certain apathy toward this matter of learning to write. The extremes of educational theory seem to meet and form a bar against composition in the eighth grade. The conservative educator thinks that formal grammar must precede writing. The radical is afraid that children will learn to write before they have anything to say. Now, heaven forbid that the child should learn how little adults say which is worth saying, or how little even the proverbs of Solomon have influenced the animal humorously called sapiens! We all agree that boys should not shed innocent ink over the "Pleasures of Anticipation" or the "Fall of Rome ;" but is it abnormal that young Knickerbockers should be able to write a decent letter by the time he is ready for algebra and the kings of England? The boy whose schooling ends with the grammar school steps out into a world that, for all its materialism, knows something of values. Good handwriting, clear and ready self-expression, the ability to read the daily paper aloud intelligibly - these things have a cash value. The subjunctive mood has not, and it cannot be demonstrated that the subjunctive has any superior, compensating moral value. 
The second reason for the reaction lies in a feeling that systematic grammar ought to make correct speakers where language lessons have failed. But systematic grammar is not systematic drill directed to eradicating errors of speech. It is an explanation, more or less illusory, of the why and wherefore of usage. Knowing why does not cure the fault. The average child is a slave to habits of wrong usage, and his only hope is to become the slave of better habits. The grammar cannot cure the faults of the language book. Only smaller classes and earnest personal effort can do that. Indeed, no book can be devised which will turn out great numbers of correct speakers as by machinery.

The third reason for the reaction is the desire to fit students properly for the study of foreign languages. It is very common for teachers of Latin to feel that their students should be good parsers and analyzers before they begin Latin. Perhaps they are right; but, if so, it may perhaps be demonstrable that the study of Latin should begin at sixteen rather than at fourteen. French is different; as a living language it can be learned without any knowledge of formal grammar, and therefore at an early age. So eminent a grammarian as Henry Sweet, in a matured statement of his views on teaching language, recently expressed a doubt whether Latin and Greek should be taught in secondary schools. This is a fact which should give us pause. One thing is certain: grammar is at present a science which applies to inflectional languages chiefly, and can best be taught through the medium of a dead language.

There is another objection to the teaching of formal grammar, namely, that grammar is at present largely traditional and unscientific. The scientific study of language is still in its infancy. It is the marvel of education that, in spite of the immense importance of linguistics, this most ancient of studies should be so little affected by modern knowledge. It is true that our scholars know much more about the physiology of sounds than their fathers did, and more about the history of words and constructions, but they have not furnished us with the principles of a universal grammar, based on a sound psychology. How far from secure are the bases of linguistics 
appears when we glance at the terminology of grammar. We lack terms for many concepts which must underlie any comprehensive science of language. Suppose, for example, that a thoughtful boy wants to know what a "word" is. A boy is far more likely to ask such questions than a collegian is, for the latter person is concerned with the forms of words. The boy might question a roomful of grammarians in vain to learn whether going is one word or several. A few would tell him that going is at least two words. Most would tell him that going is one word with various uses and ancestors, but they would presently speak of the noun going and the adjective going, and insist that the two words should not be confused. Woe to the young teacher who goes to the library, being troubled as to what "mood" is! She will learn that mood is manner, that mood is not manner but feeling, and that mood is neither manner nor feeling but a word with a certain termination or a certain ablaut. If she opens half a dozen of the best grammars used in 1902 in the best American grammar schools, she will learn the following curious things. about mood: (I) English has no moods in common use except the indicative and the imperative ; (2) English has subjunctives at present, but they are often the same in form as indicatives; (3) English has no subjunctive forms at present except in a very few verbs, but any indicative may become a subjunctive by following the word if; (4) English has no subjunctive mood except in a very few verbs, but it has a potential'mood; (5) English has no potential mood properly so called, but it has potential phrases; (6) English has an indicative mood, a subjunctive, a potential, an optative, and a conditional. Or let us suppose that the word questioned is "tense." She finds a future tense in Sweet's great grammar, but she finds Whitney speaking of the "so-called future tense," and on turning to Strong, Logemann, and Wheeler's Introduction she learns that "phrasal tenses" are properly " not tenses at all."

These absurd contradictions are not isolated or peculiar. They are easily paralleled in every branch of the grammar now taught to children. Even the analysis of sentences, which our fathers regarded as a great advance on parsing, and which 
is still supposed to furnish invaluable mental discipline, is a purely arbitrary business.

The unfortunate terms "subject" and "object" are still in use, though they cannot be defined, and though they reflect an outworn psychology. The terms "principal" and "modifier" are suggestive and helpful, but they are usually applied in a way which utterly ignores the point of interest in the sentence. The term "subject and predicate" appears in one grammar as naming the chief elements of every sentence, but across the county line another grammar insists that children should always see a subject, a copula, and a predicate - three terms instead of two. If the quarreling logicians are to set the hands of our grammarians, our teachers, and our children against each other, why should not the psychologists, or any other group of people, be represented in the grammatical terminology? Why should not a sentence consist of focus and fringe, or foreground and background, or engine, coupler, and caboose?

I close, therefore, as I began, with a plea for less grammar and more drill in usage; for less grammar and more skill in communication; for less grammar and more vocabulary - the vocabulary of noble living, as recorded in literature and biography. Nor need there be any sacrifice of system in leaving formal grammar till later in the child's life. Systematic instruction in the use of English is precisely the thing that is sacrificed to the subjunctive mood and those other vague and terrible deities.

Department of English,

E. H. LEwis.

The Lewis Institute, Chicago. 